\title{
Menumbuh kembangkan Kreativitas dalam Meningkatkan Prestasi Belajar Siswa
}

\author{
Lia Mita Syahri ${ }^{1 *}$, Ifdil ${ }^{2}$ \\ ${ }^{12}$ Universitas Negeri Padang, Sumatera Barat, Indonesia, \\ *) Correspondence regarding this article should be addressed to: Author address e-mail: \\ Liaasyahri@yahoo.com
}

\begin{abstract}
Kreativitas, siswa, dunia pendidikan, prestasi belajar memiliki hubungan yang sangat erat, dalam hal ini objek yang paling utama yaitu siswa tersebut, dimana siswa dapat mencapai hasil prestasi yang membanggakan dengan berbagai unsur atau factor salah satunya dapat berupa pengungkapan diri kreativitas pada siswa tersebut. Jika di kaji maka kreativitas itu dapat dikatakan sebagai pemecahan masalah bagi siswa dalam hal pembelajaran sesuai dengan kemampuan dan potensi yang dimiliki oleh siswa .Banyak hal yang dapat dilakukan oleh siswa dalam mewujudkan kreativitas dalam mencapai hasil prestasi belajar siswa, dalam hal-hal kecil pun bisa dilakukan oleh siswa, seperti penggunaan catatan pelajaran, penghafalan rumus dengan cara yang disesuaikan dengan tipe belajar siswa, penggunaan waktu belajar dan aktivitas yang bisa membuat efektif antara waktu belajar dan aktivitas lainnya.Kreativitas yang dapat dilakukan oleh siswa dapat berdampak dengan hasil belajar siswa yang membanggakan, sehingga dapat dikatakan bahwa siswa itu memiliki prestasi dalam belajar, dengan bukti siswa mendapatkan nilai yang memuaskan yang sesuai dengan proses pembelajaran selama dilakukan oleh siswa. Peroleha nilai atau tindakan dan sikap siswa yang baik memang merupakan bukti bahwa prestasi tersebut telah dicapai oleh siswa, maka dari itu kreativitas memiliki peranan dalam hal prestasi belajar. Sedangkan dalam segi belajar, siswa dapat dikatakan memiliki prestasi apabila sikap dan tingkah lakunya itu terjadi perubahan yang maju atau baik dari sebelumnya, maka dari itu apa yang dinamakan belajar dapat dikatakan berhasil.
\end{abstract}

Keywords: Kreativitas, Prestasi Belajar

Article History: Received on 05/07/2019; Revised on 15/08/2019; Accepted on 20/08/2019; Published Online: $31 / 08 / 2019$. distribution, and reproduction in any medium, provided the original work is properly cited. (C2019 by author.

\section{PENDAHULUAN}

Kreativitas dengan prestasi belajar, memiliki hubungan yang erat, dengan melakukan kreativitas terlebih dahulu dengan teknik dan cara yang disesuaikan dengan prinsip kreativitas bagi siswa, maka dampak dari hasil kreativitas itu dapat dirasakan oleh siswa, yakni siswa memiliki prestasi dalam belajarnya, memperoleh nilai yang baik, 
sikap dan tingkah laku yang berubah kearah yang lebih baik. Dalam hal kata kreativitas dapat diartikan menurut Hurlock (dalam Sudarma, 2013) bahwa "usaha yang dilakukan oleh individu (siswa) dalam menghasilkan sesuatu yang baru baik berupa ide, gagasan, karya atau objek dan hal lainnya yang disusun dalam susunan yang baru". Maka dari itu gagasan atau ide yang dapat dicipatakan siswa atau ditemui oleh siswa untuk mendapatkan prestasi belajar yang membanggakan dengan salah satu cara yaitu kreativitas adalah usaha yang dapat membuat siswa mampu membanggakan dan mengoptimalkan potensi atau bakat siswa dalam belajar.

Lain halnya dengan belajar yang diartikan dengan menurut Hilgard (dalam Abu, 2009) seseorang yang dikatakan belajar dimana terjadi perubahan sikap dan perilaku kearah yang maju pada diri individu (siswa) bukan hanya di intelektual, perubahan itu dapat dilihat dari keseharian atau tindakan yang dilakukan siswa, tentunya sikap atau tingkah laku yang memiliki manfaat atau positif bukan ke tingkah laku negatif'. Jadi dapat kita simpulkan, menggapai prestasi belajar bagi siswa itu bukan hanya dibuktikan dengan nilai atau piala yang mereka dapatkan, tapi dari sisi lain prestasi belajar yang membanggakan juga dapat dibuktikan bahwa proses pembelajaran itu berhasil jika siswa memiliki sikap yang baik dan tingkah laku yang positif yang bisa membawa manfaat dalam kehidupan sehari-harinya, misalnya saja siswa mau berdiskusi dengan teman lain dalam memecahkan permasalahan tentang pembelajarannya.

\section{PEMBAHASAN}

\section{Konsep Kreativitas}

Kreativitas merupakan keistimewaan yang didapatkan oleh setiap individu, memiliki ide-ide yang cemerlang, mampu menyelesakaikan permasalahannya, mampu bertindak dan berani mengemukakan pendapat dan masih banyak lainnya, setiap individu di beri keistimewaan dengan kreativitas, apalagi siswa yang diberi kesempatan untuk dapat mewujudkan kreativitas tersebut, terutama dalam hal pembelajaran, sedangkan menurut Haefele "kemampuan yang dilakukan oleh individu tersebut, mampu menghasilkan kombinasi atau hal-hal baru sehingga bukan hanya memiliki hasil intelektual tetapi juga ada hasil tehadap sosial individu tersebut". Begitu halnya juga dengan siwa, siswa mampu menggabungkan atau mengahsilkan kombinasi baru dalam proses pembelajarannya, mungkin saja dengan menkombinasikan tipe belajar dengan metode belajar siswa maka menghasilkan gaya belajar yang sesuai dengan siswa, maka dapat dikatakan kreativitas belajar berhasil dilaksanakan oleh siswa.

\section{Prinsip-prinsip dari Kreativitas}

Menumbuhkan kreativitas tidak dapat dilaksanakan dengan mudah, banyak hal yang dilakukan agar siswa mampu melaksanakan kreativitas itu, sesuai dengan kemampuan diri dan tuntutan keberhasilan dari kveativitas itu sendiri, jadi pelaksanaan kreativitas itu tidak dapat hasilnya dibuat-buat, memang terbukti dan dapat diaplikasi dalam kehidupan sehari-hari. hasilnya itu didapatkan secara penelitian dan alamiah. 
Membuang fikiran negative tentang kegagalan dalam melaksanakan kreativitas, berani mengambil resiko tetapi tetap memikirkan hambatan-hambatan yang akan terjadi, berani bertanggung jawab terhadap memaparkan dan melaksanakan hasil dari kreativitas yang telah didapatkannya.

\section{Proses dari Kreativitas}

Tentunya dalam mencapai kreativitas dan mendapatkan hasil dari kreativitas yang dilaksanakan siswa dalam proses belajarnya, tentu ada beberapa proses yang harus dilakukan siswa agar tercapainnya kreativitas dalam belajar dan mampu menggampai prestasi belajar yang membanggakan dengan salah satu bukti yaitu mendapatkan suatu gagasan baru, nilai selama proses pembelajaran dan perubahan tingkah laku yang positif.

Dapat kita ketahui proses dari kreativitas menurut Parnes ( dalam Khairani dan Darnis, 2000) yaitu: "(1) Fluency (2) Flexibility (3) Orinality (4) Erabolation (5) Sensivity". Dengan penjelasan : Fluency (Kelancaran): siswa mampu dan berani tanpa ada rasa takut dalam artian lancar dalam mengemukakan pendapat, idea atau gagasan baik yang serupa atau tidak dalam menyelesaikan permasalahan pembelajarannya. Flexibillity (Keluwesan): siswa memiliki wawasan yang luas dalam menyelesaikan permasalahan dengan cara diluar hal yang biasa saja dilakukan. Orinality (keaslian): dimana siswa dalam mengemukakan pendapat, ide atau gagasan nyaatau merespon hal itu dapat dilakukan dengan cara hal-hal yang baru atau unik

Erabolation (Keterperincian): dimana siswa jika telah mendapatkan hasil dari proses kreativitasnya, maka siswa dapat mengemukakan idenya dengan jelas dan rinci tentunya ide nya dapat dilaksanakan dalam kehidupan sehari-hari Sensivity (Kepekaan): siswa mampu merespon atau mengerti dengan hasil kreativitas tersebut tentunya tanggapan atau respon itu sesuai dengan permasalahan yang dijabarkan.

\section{Konsep Belajar}

Belajar merupakan aktivitas yang bukan hanya dilakukan oleh seseorang yang sedang menempuh pendidikan, dari segi apapun, baik umur atau jenis kelamin, semuanya pernah merasakan yang namanya belajar, ada yang mengatakan belajar itu dapat dilakukan dimana saja, baik dri segi pengalama hidup sendiri atau pengalaman individu lain, lingkungan sekitar dan masih banyak lagi.

Sehubungan dengan hal tersebut menurut (Abu, 2009)"dikatakan individu itu belajar, apabila individu tersebut setelah belajar menghasilkan tingkah laku baru yang mengarah ke arah positif, dan jika tingkah laku itu tetap pada keadaannya maka dapat dikatakan bahwa proses belajar yang individu lakukan itu bukanlah belajar"

Maka dapat kita simpulkan bahwa, siswa jika telah berhasil dalam belajar maka juga dapat dibuktikan bahwa, sikap atau tingkah laku siswa itu berubah kearah yang positif, berarti dapat kita simpulkan juga pembuktian dari tercapainya proses belajar bukan hanya dinilai dengan hasil intelektual, tetapi sikap atau tingkah laku juga termasuk bukti yang disesuaikan dengan hasil sosial siswa. 


\section{Ciri-ciri Belajar}

Belajar memang dapat dilakukan dimanapun, kapanpun, dengan siapa dan dalam apapun, tetapi tidak semua hal tersebut dapat dikatakan berhasil mencapai dari hasil belajar tersebut, dalam dunia nyata saja atau dalam kehidupan sehari-hari, banyak individu yang telah mengetahui dari proses belajar bahwa membuang sampah sembarangan itu dilarang, tetapi dapat kita temukan saja, banyak juga individu yang masih membuang sampah sembarangan dengan berbagai alasan yang individu kemukan. Jadi Ciri-ciri belajar menurut (Khairani dan Darnis, 2000) ialah: "(1) Belajar Menyebabkan Perubahan (2) Belajar adalah perbuatan sadar (3) Belajar terjadi melalui pengalaman (4) Belajar seperti perubahan (5) Belajar adalah proses interaksi". Dengan penjelasan sebagai berikut:

Menyebabkan Perubahan: samahalnya bahwa setelah individu tersebut belajar, maka individu tersebut terjadi perubahan tingkah laku dalam dirinya kearah yang lebih baik. Perbuatan Sadar: maksudnya disini individu mengetahui alasan mengapa ia belajar, apa kegunaannya dia belajar, apa manfa'at dan tujuan kenapa individu tersebut belajar Pengalaman: Dimanapun ,kapanpun, siapapun, belajar itu dapat dilaksanakan, dari segi pengalam individu tersebut atau belajar dari pengalaman individu lain, tentunya dalam belajar individu tersebut yang langsung memahami arti dari proses belaajarnya artinya tidak dapat digantikan. Seperti Perubahan: yaitu perubahan dari segi yang paling utama yaitu tingkah laku dan sikap, dan dengan hal-hal lainnya yaitu moral, ucapan, lisan dan keterampilan siswa.

\section{Metode Belajar}

Secara umum metode merupakan suatu usaha atau jalan atau juga upaya dalam mencapai tujuan yang individu inginkan, dan tentunya keberhasilan dalam mencapai hal tersebut, jika dikaitkan dengan proses pembelajaran untuk mencapai prestasi belajar yang membanggakan bagi siswa, maka individu sendiri harus lebih mengetahui tujuan dari kita belajar itu. Menurut (Sumanto, 1995) "Tujuan dari individu belajar, individu mendapatkan wawasan baru, pemahaman, pengetahuan, informasi , sikap dan tingkah laku, yang dimana akan di aplikasikan oleh individu tevsebut dalam kesehariannya"

Maka banyak hal yang dapat dilakukan oleh siswa dalam melaksanakan metode pembelajarannya, ada beberapa metode yaitu: Pembuatan Jadwal dan Pelaksanannya: siswa mengatur jadwal belajarnya dengan aktivitas lainnya, agar adanya kedisiplinan dan keteraturan dalam keseharian siswa

Membaca dan Membuat Catatan: merupakan metode yang termasuk penting dalam proses belajar, dengan adanya siswa membaca maka wawasa, ilmu pengetahuan dan informasi siswa akan bertambah, dengan membuat catatan maka dapat dikatakan siswa telah mengerti dan menangkap inti-inti atau makna dari hasil siswa selama belajar Mengulangi bahan pelajaran: ini bermaksud, agar siswa terus mengingat dan mampu mengulangi kembali hasil pelajaran yang ia telah dapatkan, dengan maksud jika siswa 
dapat mengulangi hasil belaajar maka daya ingat siswa terhadap pembelajaran dapat dikatakan berhasil Mengerjakan Tugas: ini merupakan bukti bahwa siswa telah memahami metari pembelajaran dan bertanggung jawa atas tugas yang ia terima, seperti dalam hal kebiasaan siswa yaitu membuat PR atau tugas sekolah.

Dalam hal upaya, sebenarnya banyak upaya yang dapat dilakukan siswa dalam menumbuhkembangkan kreativitas dalam hal mencapai prestasi belajar yang membanggakan, tentunya itu tidak terlepas dari keinginan atau motivasi yang kuat oleh siswa dalam mengembangkan kreativitas yang ada pada dirinya, karena menyelesaikan permasalahan apalagi bersangkutan dengan masa depan siswa merupakan hal yang sangat penting, agar dunia pendidikan bangsa dan generasi penerus dapat mewujudkan cita-cita bangsa ini, tentunya kreativitas termasuk dalam hal membanngakan anak bangsa dengan menggapai prestasi belajar yang gemilang. Sesuai dengan metode yang dilakukan, yaitu:

1. Membuat Jadwal dan pelaksanaan belajar dengan rutinitas lainnya

2. Membaca sebagai jembatan ilmu, dan menuangkannya kembali ke dalam bentuk catatan agar mudah dipahami

3. Terus belajar dengan mengulang-ulangi bahan pelajaran, agar dapat diingat dan bisa diterapkan dalam kehidupan siswa sehari-hari

4. Dan yang paling inti, siswa memiliki sikap tanggung jawab dalam mengerjakan tugas yang siswa miliki.

Hal itu semua tentunya disesuiakan dengan gaya belajar setiap siswa, sikap siswa, keadaan lingkungan belajarnya, fasilitas belajarnya, minat dalam belajar dan potensi atau bakat bahkan kemampuan siswa.

\section{KESIMPULAN}

Setiap individu itu mampu untuk melakukan tindakan kreativitas, terutama siswa dalam mencapai prestasi belajar siswa yang membanggakan, keinginan atau motivasi yang kuat dari dalam diri siswa untuk menggapai keberhasilan dan cita-cita belajar, dapat menumbuhkembangkan kemauan siswa dalam melakukan tindakan yang kreatif atau melakukan kreativitas dalam hal pembelajarannya, banyak cara yang dapat dilakukan siswa dalam menumbuhkembangkan kreativitas sehingga berdampak baik kepada hasil pembelajarannya yaitu berprestasi, mengatur jadwal belajar, menghafal rumus atau pelajaran yang disesuikan dengan gaya belajar siswa, mengulangi pelajaran, disiplin dan bertanggung jawab dalam hal proses pembelajaran tentunya bertanggung jawab dalam mengerjakan tugas.

Tentunya jika itu berhasil dilakukan oleh siswa maka bukti siswa itu telah bisa mandapatkan prestasi belajarnya yaitu mendapatkan nilai yang memuaskan, penghargaan, rasa bangga dan utamanya sikap dan tingkah lakunya itu terjadi perubahan kearah yang lebih baik, maka kreativitas sebagai upaya prestasi belajar siswa dapat tercapai oleh siswa tersebut. 
60 Menumbuh kembangkan Kreativitas dalam Meningkatkan.....

\section{REFERENCES}

Abu, A. (2009). Psikologi Sosial (EdisiRevisi). Jakarta: Rineka Cipta.

Khairani dan Darnis, A. (2000). Buku Ajar perkembangan dan belajar peserta didik. Padang: DIP Universitas Negeri Padang.

Sudarma, M. (2013). Mengembangkan keterampilan berpikir kreatif. Jakarta: Raja Grafindo Persada.

Sumanto. (1995). Psikologi Umum. Yogyakarta: Buku Seru. 